\title{
バイオフィードバック法による下顎位の改善
}

\author{
山 形 光i 孝
}

\section{Improvement of Mandibular Position Using Biofeedback Method}

\author{
Mitsutaka Yamagata
}

\begin{abstract}
Watanabe and others reported the efficacy of the application of the Electromyogram biofeedback method for occlusal diagnosis and treatment in patients with arthrosis of the TMJ. They also found the mandibular position induced by this method quite stable physiologically, and they named this position PCP or Physiological Centric Position.
\end{abstract}

We report a case of infraocclusion and problems in horizontal mandibular relationship in which a simple method of EMG biofeedback was used, depending only on the fingertip palpation to improve mandibular relationship as part of oral rehabilitation.

\section{緒言}

渡辺らは, EMG (Electromyogram) バイオ フィードバック法を顎関節症患者に応用し，その 咬合診断や治療への有効性を報告している11. ま た, 同法によって導びかれる下顎位を PCP(Physiological Centric Position) と命名し生理的にき わめて安定した位置としている.

今回, 自賞するような顎関節症状は認めなかっ たが，低位咬合で水平的な下顎位にも問題がある と思われる症例の咬合再構築にあたり, 手指の感 覚を利用した $\mathrm{EMG}$ バイオフィードバックの簡便 法を用い, 下顎位の改善を試みた 1 症例について 報告する。

\section{症例}

患 者：77 歳, 男性.
初 診: 1997 年 9 月 16 日.

主 訴: 上顎総義歯の不適合.

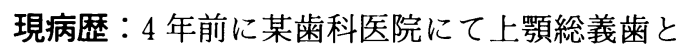
下顎局部床義歯を作製したがしだいに適合が悪く なり，ここ 2,3 年は義歯安定剤を使用している.

現 症: 口腔内所見; 上顎は, 咬合平面の乱れ が大きく，粘膜面に義歯安定剤が使用されている 総義歯を装着している.下顎は $321 \| \longdiv { 3 7 }$ の歯牙 が存在し, 久損部には不安定な局部床義歯を装着 している. 17は動摇度 3 で保存不可能の状態で あった，上顎前歯部舌側床には，下顎現在歯によ る圧痕が認められる。 $7-4,2 \nmid 7$ 部の顎堤は高 度に吸収している（図 1〜4）。

その他の所見; 最大開口量は右側中切歯間で $35 \mathrm{~mm}$ で, 開口時抵抗感があり右側への偏位が認 められるが, 開閉口時に疼痛はない. 触診では, 右側咬筋および右側顎関節部に圧痛が認められる がその他の咀嚼筋に異常は認められない.クリッ ク音, 頭痛, 肩こりなどもない.

上下赤唇の面積は狭く, 両側口角が下方に垂れ 下がり，深い皺を伴っており，下顎前突感がある。 


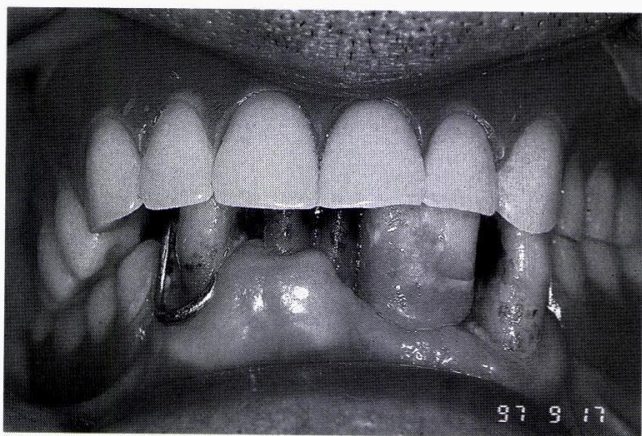

図 1 3クラスプの位置から，下顎枵堤の 吸収変化が著しい。下顎前歯が上顎 義歯を強くつき上げている.

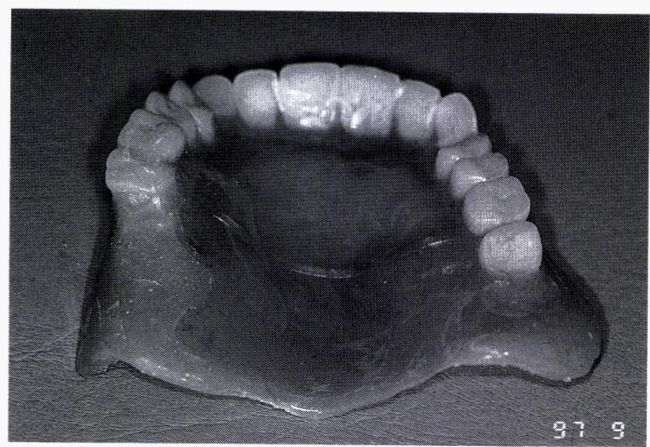

図 3 咬合平面は乱れ左右で人工歯の位置 を大きく変えている.

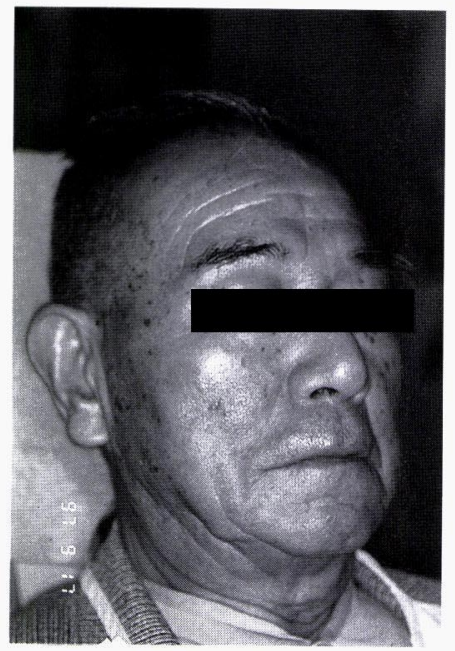

図 5 口唇，口角および下 顎前突感から低位咬 合をうかがわせる。

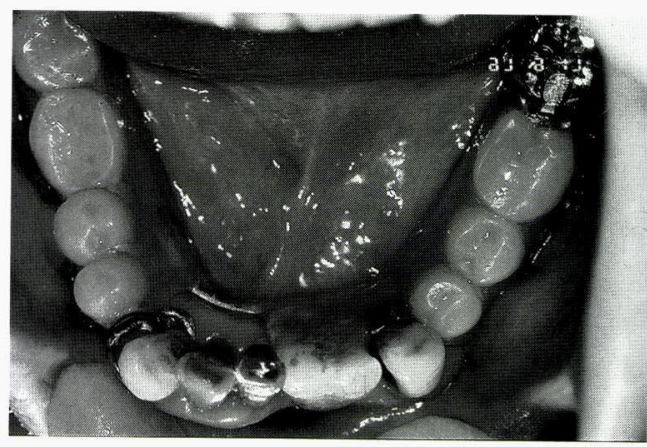

図 2 上䫓前歯部へのつき上げは，下顎臼 歯部のさらなる吸収変化につながり 義歯の咬合はますます悪くなる。

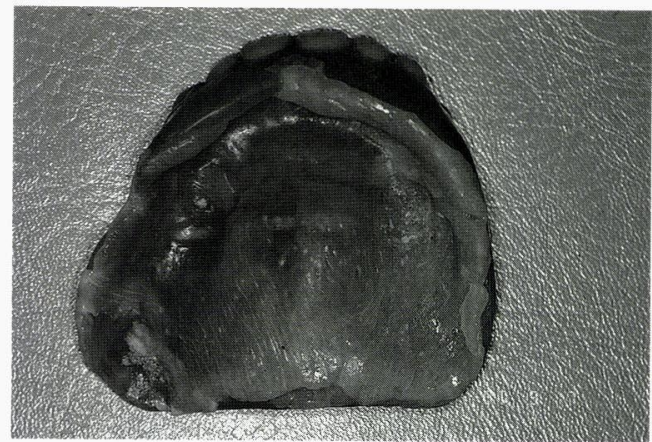

図 4 咬合の乱れは顎堤を变化させ，䪽堤 の変化はさらなる咬合の乱れを招 く. 義歯安定材を使用しても安定が 得られない状態となっている.

低位咬合をうかがわせる顔貌である（図５）。

\section{診断および治療方針}

現症より，上下義歯の不適合，低位咬合，下顎 の偏位が疑われ，下顎位の改善を考えた補綴修復 処置が必要と診断した。

上顎総義歯の改修は困難であったため, 解剖学 的平均値などを参考に前歯の位置や咬合平面を修 正した治療用義歯を作製することとした（図6）。 下顎は旧義歯を利用し，咬合平面を即時重合レジ ンを用いフラットなテーブルに改修した。

咬合高径については，下䫈前歯やモラーパット を参考に設定し，水平的な下顎位の誘導に関して は，手指を用いたバイオフィードバック法の簡便 法を利用することにした。 


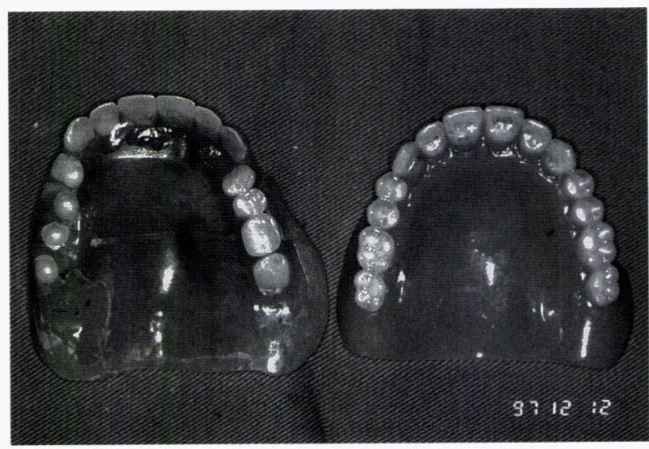

図 6 旧義歯の改修では十分でなかったた め，歯列弓，咬合平面を改善した治 療用義歯をつくる.

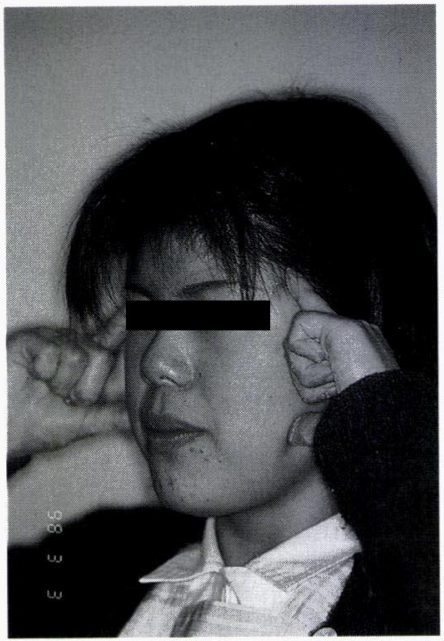

図 8 手指の感覚を利用し たバイオフィード バック法の実際

$\mathrm{EMG}$ バイオフィードバック法は，左右の咬筋 から表面電極によって導出した $\mathrm{EMG}$ をミキシン グ後, 聴覚信号として患者にフィードバックし, 上下顎のタッピング運動に伴う咀嚼笳活動をコン トロールさせ，生理的な顎位へと誘導するもので ある (図 7$)^{2)}$.

今回は聴覚信号の代わりに，歯の接触時の咀嚼 筋の収縮によるふくらみを患者自身の手指で触知 しその感覚を信号とした簡便法 ${ }^{3)}$ を利用した。

実際には，左右の示指で側頭筋前腹，親指で咬 筋浅腹を触知させ，タッピング運動の強弱による 筋収縮の大きさを患者に認識させ，筋収縮が触知

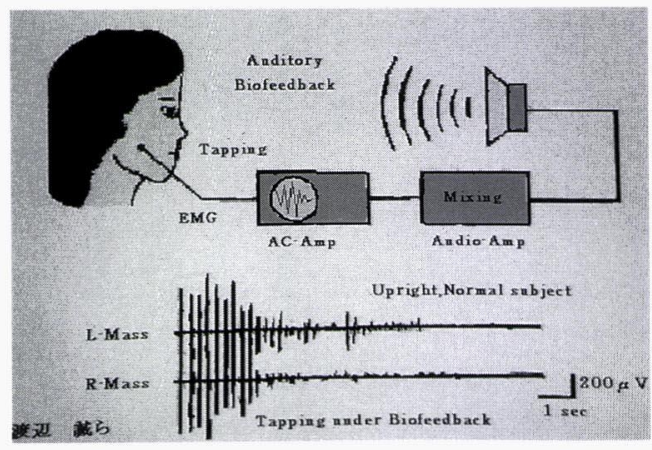

図 $7 \mathrm{EMG}$ バイオフィードバック法の原理 ${ }^{2)}$

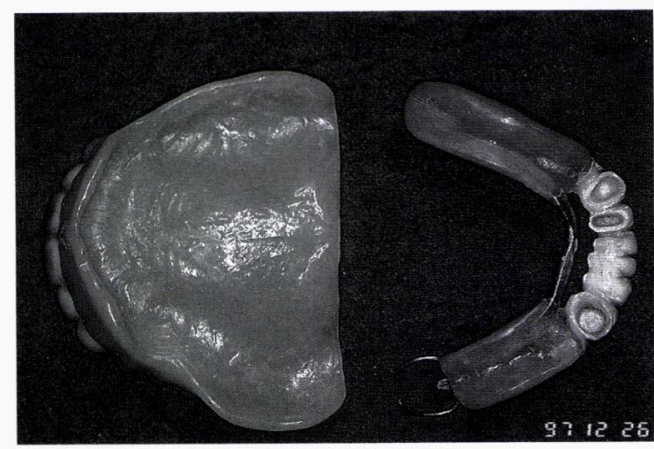

図 9 下顎義歯の安定を高めるため，下顎 前歯をコーヌスタイプの仮義歯に改 修した。

できるかできないかの最小の力でのタッピングを 習得させる。姿勢は，へッドレストから頭をはず し，上体および顎位を垂に保ったアップライト位 でまた，肩や腕の力をぬきリラックスした状態 で行う(図 8 ). 、タピング運動の頻度は, 反復性 の反射運動を有すると考えられる高頻度のタッピ ングであることが望ましく, 通常 3〜 4 Hzの夕ッ ピングを行わせる。診療所だけでなく，家庭にお いても同様のタッピング運動の練習を指示する.

\section{処置および経過}

上顎に治療義歯，下顎に咬合平面をフラット テーブルにした旧義歯を装着しバイオフィード バック法を応用したところ, 治療開始 7 日後に下 顎の左方移動が大きく認められ，同時に左側前歯 部の接触, 右側臼歯部の離開が認められた。ほぼ 同時期に開口時の抵抗感が消失し，開口量が 35 

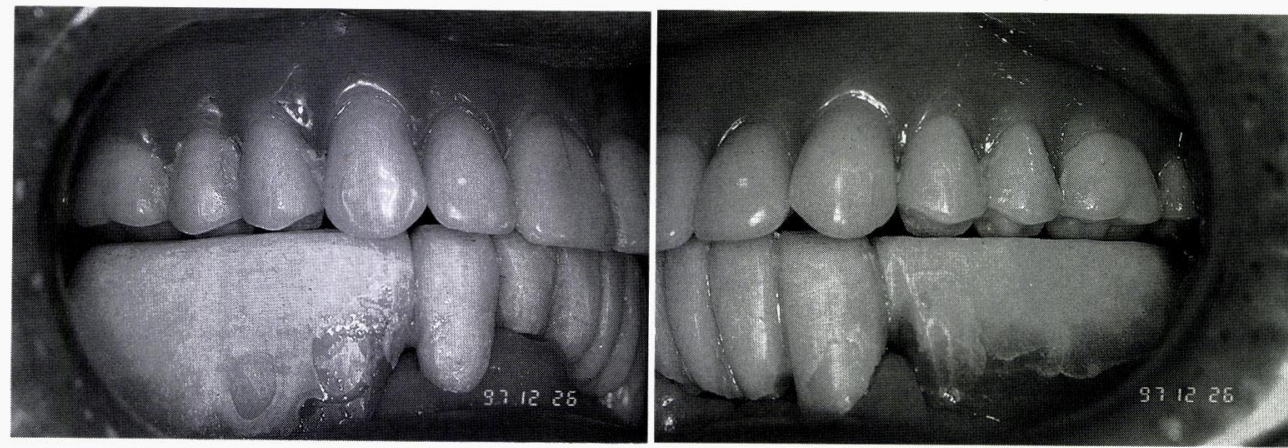

図 10, 11 上顎舌側咬頭頂のみが下顎のフラットテーブルに接触するように調整する.

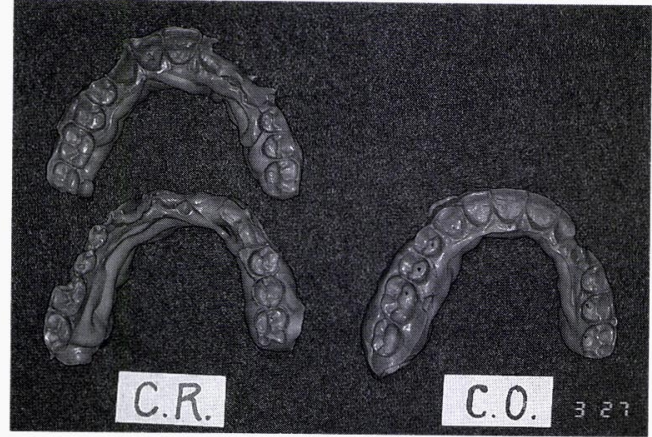

図 12 セントリックバイト 2 枚と咬頭嵌 合位でのバイト

$\mathrm{mm}$ から $49 \mathrm{~mm}$ へと増加し，右側顎関節部の圧 痛も緩和した。

その後, 右側フラットテーブルのレジン添加や 咬合調整を行い，さらに下顎義歯の安定性を高め るため，下顎前歯部をコーヌスタイプに修正した (図 9 ).

咬合接触は, 上顎舌側咬頭頂のみがフラット テーブルに接触するようにし，上䪽煩側咬頭，上 下前歯は接触しないように調整した（図 10, 11）。 治療開始 2 力月後，セントリックバイトと咬頭 嵌合位が同一顎位を示すか否かを調べるため，ス プリットキャスト法にて評価を行った。セント

リックバイトの咬合採得は，患者の覧部に術者の 手指を力を加えることなく軽く添え，そっと閉口 してもらい，上下歯が接触する直前の状態を採得 した い, セントリックバイト 2 枚, 咬頭嵌合位におけ るバイトを 1 枚採得した(図 12)。この時点での 3
枚のバイトによるスプリットキャストの一致は認 められず，同一顎位の再現は得られていないもの と思われた（図 13, 14）。

その後もバイオフィードバック法を実施しなが ら咬合調整を続け,さらに 1 力月後同様にスプ リットキャスト法にて下顎位の評価を行った. 2 枚のセントリックバイトでスプリットキャストの 一致が確認され, かつ咬頭嵌合位のものとも一致 していた(図 15，16)。すなわち中心位と咬頭嵌合 位が一致したことになる。

この時点で, 下顎位の安定が得られたと判断し, 最終補綴治療へと進むこととした。

\section{考察}

口腔内や顎関節の所見から，下顎右側臼歯部の 顎堤の吸収による下顎局部床義歯の沈下や，人工 歯の咬耗が原因で，それを補償するために，右側 下顎頭の偏位が生じたのではないかと推測した。 前述したように，バイオフィードバック法実施後 7 日目に, 下顎左方移動, 左側前歯部の接触, 右側 臼歯部の離開などの下顎位の変化が見られた。こ のことは，咬合高径を回復し，タッピング時の筋 活動を自発放電レベルとほぼ同一状態にコント ロールすることにより，後上方に偏位していたと 思われる右側下顎頭が，前下方の生理的な位置に 誘導されたためにおきたものと考えている。この 時点で, 開口量が増加し抵抗感がなくなったこと や，顎関節部の圧痛が緩和したことなどもそのこ とを董付けていると考えることができる. 

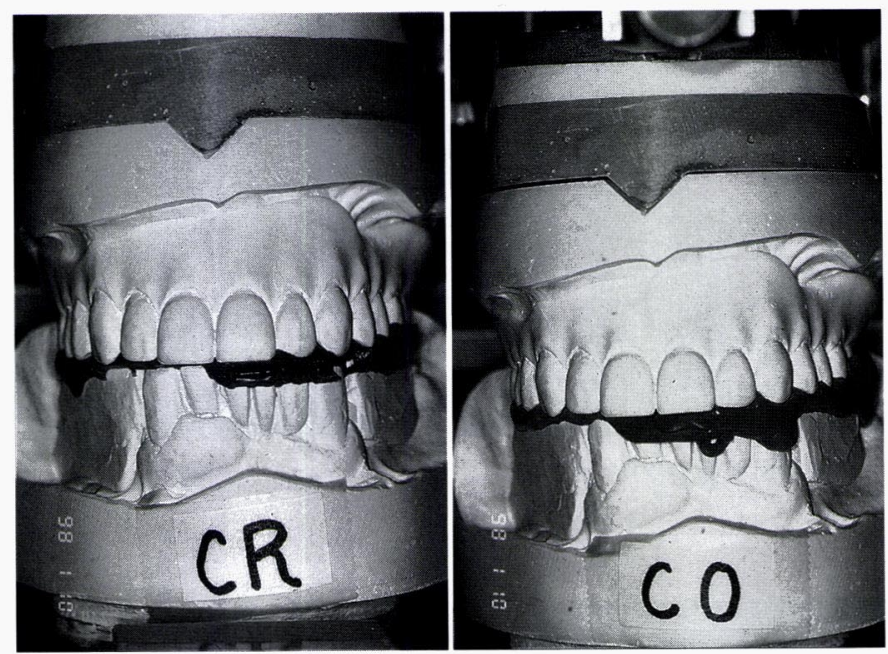

図 13,14２枚のセントリックバイトと咬頭嵌合位でのバイ トによるスプリットキャストの一致は認められな かった。
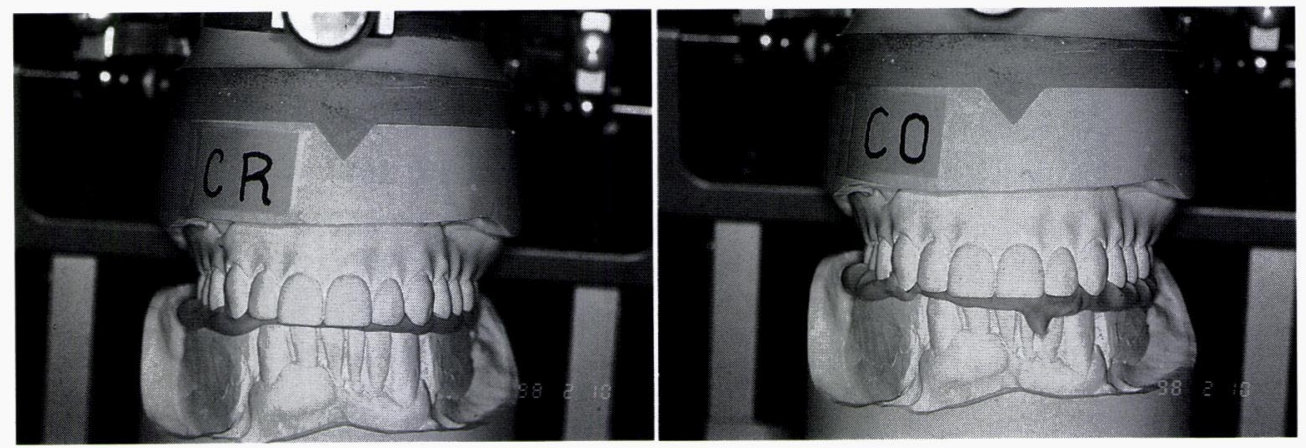

図 15, 163 枚のすべてのバイトでスプリットキャストの一致が見られ, 下頡位は安定し再 現性の高い状態となっている。

今回は下顎位の安定度を評価するのに, スプ リットキャスト法を用いた。最初の治療開始後 2 カ月目の評価においては, 3 枚のすべてのバイト で, スプリットキャストの一致が認められなかっ た.これは, 下顎位の安定が十分得られていない ことを示すもので, 下顎旧義歯の調整や, コーヌ スタイプに改修したりするのに時間がかかったこ とも原因の 1 つと考えられる.義歯の安定に伴い, 患者のタッピング運動にも上達が感じられた.さ らに 1 カ月後には, タッピングポイントも収束し, 調整も不必要となった。 その時点でのスプリット キャスト法の評価では, 3 枚のすべてのバイトで スプリットキャストの一致が見られ, 下頡位は安
定し, 再現性の高い状態となっている. 義歯の安 定度が治療期間と下顎位の再現性の精度を左右す るものと思われる。

今後最終補綴物作製へと移行するが，その調整 にも同法を応用し, 経過を観察していきたいと 思っている.

\section{ま と め}

手指の感覚を利用したバイオフィードバック法 は, 左右の咀嚼関連筋群を調和のとれた活動とし, 下顎を適正な位置へと誘導するといわれている. 本症例は, 高齢にもかかわらず, 短期間で下顎位 
の大きな改善が得られたことは, バイオフィード バック法が下顎位の改善に有効な手段であること を示唆している。

\section{参考文献}

1) 渡辺誠, 佐々木啓一, ほか: 䫟関節症 (Temporomandibular Disorder)の診断と治療. 補経 誌, 41(1) : 1-43, 1997.

2）渡辺 誠：頻関節症の保存療法. デンタルオリ ンピア'95 21 世紀の歯科医療。歯界展望, 別 冊 : 125, 1996.

3）渡辺誠, 佐々木啓一, ほか: バイオフィード
バックを応用した咬合治療. 顎関節症の診断と 治療 咬合からのアプローチ, 補綴臨床, 別冊： 262, 1985 .

4）菅野博康：咬合採得時の下顎位を考える。顎咬 合誌, $12(2) ： 47-55,1991$.

別刷請求先 : 山形光孝

山形歯科クリニック 